\title{
Chert and obsidian procurement of three Corsican sites during the 6th and 5th millenniums $\mathrm{BC}$
}

\author{
Céline S. Bressy ${ }^{\mathrm{a}, *}$, André D’Anna ${ }^{\mathrm{a}}$, Gérard Poupeau ${ }^{\mathrm{b}, \mathrm{c}}$, \\ François-Xavier Le Bourdonnec ${ }^{b}$, Ludovic Bellot-Gurlet ${ }^{\mathrm{d}}$, \\ Franck Leandri ${ }^{\mathrm{a}, \mathrm{e}}$, Pascal Tramoni ${ }^{\mathrm{a}, \mathrm{f}}$, \\ Frédéric Demouche ${ }^{\mathrm{g}}$ \\ a LAMPEA, UMR 6636, CNRS-université de Provence, MMSH, LAMPEA, 5, rue du Château-de-l'Horloge, \\ BP 647, 13094 Aix-en-Provence, France \\ ${ }^{\mathrm{b}}$ UMR 5060, CNRS-université Bordeaux-3, CRP2A-Maison de l'Archéologie, Esplanade des Antilles, 33607 Pessac, France \\ c UMR 5198, département de Préhistoire, Muséum national d'histoire naturelle, 1, rue René-Panhard, 75013 Paris, France \\ d LADIR, UMR 7075, CNRS-université Paris-6, 2, rue H. Dunant, 94320 Thiais, France \\ e DRAC/SRA de Corse, 19, cours Napoléon, 20181 Ajaccio, France \\ ${ }^{\mathrm{f}}$ Institut national de recherches archéologiques préventives (INRAP) Méditerranée, 13100 Aix-en-Provence, France \\ g Musée départemental de Préhistoire corse et d'archéologie, rue Croce, 20100 Sartène, France
}

Received 10 December 2007; accepted after revision 29 February 2008

Available online 16 April 2008

Presented by Philippe Taquet

\begin{abstract}
Provenance studies of Corsican siliceous raw materials used during, the Neolithic focused mainly on obsidian. They showed an almost systematic use of Monte Arci sources (Sardinia). Chert studies have long been dodged, whereas the multiplicity of potential origins, in Sardinia and in continental areas, may provide complementary spatial information about diffusion patterns and interaction phenomenon in the Middle Tyrrhenian during the Neolithic. We studied obsidian and chert industries of three Corsican sites: Renaghju (Early Neolithic), Monte Revincu and Vasculacciu (both Middle Neolithic). In order to assign a provenance, 2241 chert archaeological samples were characterized by petrographic approaches and 100 obsidian artefacts were submitted to geochemical analyses. Each site provides a specific trend regarding relative abundances of raw materials, provenance and consumption patterns. Considered in the wider perspective of the Neolithic Corsican context, results reveal procurement variations from a chronological as well as a geographical point of view. Those variations may echo economic and social evolutions undergone in Neolithic societies of the Tyrrhenian area. To cite this article: C.S. Bressy et al., C. R. Palevol 7 (2008).
\end{abstract}

(C) 2008 Académie des sciences. Published by Elsevier Masson SAS. All rights reserved.

\section{Résumé}

Approvisionnement en silex et en obsidienne de trois sites corses des $\mathbf{V I}^{\mathbf{e}}$ et $\mathbf{V}^{\mathbf{e}}$ millénaires. Les études de provenance des matériaux siliceux employés en Corse au Néolithique se sont principalement focalisées sur l'obsidienne, montrant quasi systématiquement une utilisation des sources du Monte Arci (Sardaigne). Cependant, l'identification de l'origine du silex, compte tenu de la diversité des sources potentielles distribuées en Sardaigne et sur le continent, peut apporter des informations spatiales complémentaires sur les phénomènes de circulation et de diffusion. L'origine de ces matériaux lithiques importés en Corse a été

\footnotetext{
* Corresponding author.

E-mail address: cbressy@mmsh.univ-aix.fr (C.S. Bressy).
} 
déterminée par des approches pétrographiques (2241 échantillons de silex) et géochimiques (100 échantillons d'obsidienne), pour trois sites en cours d'étude : Renaghju (Corse-du-Sud), daté du Néolithique ancien, Vasculacciu (Corse-du-Sud) et Monte Revincu (Haute-Corse), datés du Néolithique moyen. Mis en perspective avec d'autres analyses disponibles par ailleurs, les résultats révèlent sur un plan chronologique (Néolithique ancien et moyen) et géographique (Nord et Sud) des variations d'approvisionnements en terme de nature et d'origine des matériaux. Ces variations reflètent les évolutions économiques et sociales rythmant les premières sociétés néolithiques de l'aire tyrrhénienne. Pour citer cet article : C.S. Bressy et al., C. R. Palevol 7 (2008).

(C) 2008 Académie des sciences. Published by Elsevier Masson SAS. All rights reserved.

Keywords: Corsica; Neolithic; Chert; Obsidian; Provenance

Mots clés : Corse ; Néolithique ; Silex ; Obsidienne ; Provenance

\section{Introduction}

The first Holocene populating of Western Mediterranean islands started during the 9th millennium $\mathrm{BC}$ $[11,13]$. In Corsica, nine Mesolithic sites were attributed to the 9th and 8th millennium BC $[10,30]$. In those settlements, local resources from the Hercynian basement, the Alpine lustrous shales and volcanic rocks, were exploited (Fig. 1), in particular filonian quartz and rhyolites $[14,39,58]$.

The Neolithisation of Corsica occurred during the 6th millennium BC with the spread of the Cardial culture $[3,5,6,26,57]$. Currently, following a revisited Neolithic chronology [50], about 25 sites related to this culture are known in Corsica. After an apparent reduction of the number of sites during the 5th millennium, the number of settlements dated from the 4th millennium is much more important. From the Earliest Neolithic sites, allochtonous raw materials, obsidian and chert, appeared in large quantities in Corsica, constituting a significant part of lithic implements beside local materials.

The nearest obsidian sources are those of the islands of Sardinia, Lipari, Palmarola and Pantelleria. Several obsidian provenance studies based on elementary compositions have shown that the Neolithic obsidians of Corsica came almost exclusively from Sardinia $[18,27-29,51,52,55]$, where they are associated with the Monte Arci volcanic massif. The only known exception is about one artefact from the site of Castiglione (Oletta), dated by ${ }^{14} \mathrm{C}$ between 7004 and $6620 \mathrm{cal} \mathrm{BC}$, which originates from Palmarola [47].

Scarce reworked centimetre-sized chert pebbles have been discovered along the northern coast of Corsica [43], and hydrothermal silicifications might occur occasionally in the massifs of Alpine Corsica. However, the most important and closest potential chert outcrops are located in Sardinia, either in the Oligo-Miocene basin of Perfugas (Anglona) or in the vicinity of the Oristano bay (Fig. 1). However, our current knowledge of Sardinian chert sources may not be exhaustive. For long, chert provenance assignments in Corsica, when mentioned in the literature, rested on assumptions or visual matching with Sardinian sources [17]. Petrographic chert sourcing has only been investigated recently $[8,9]$.

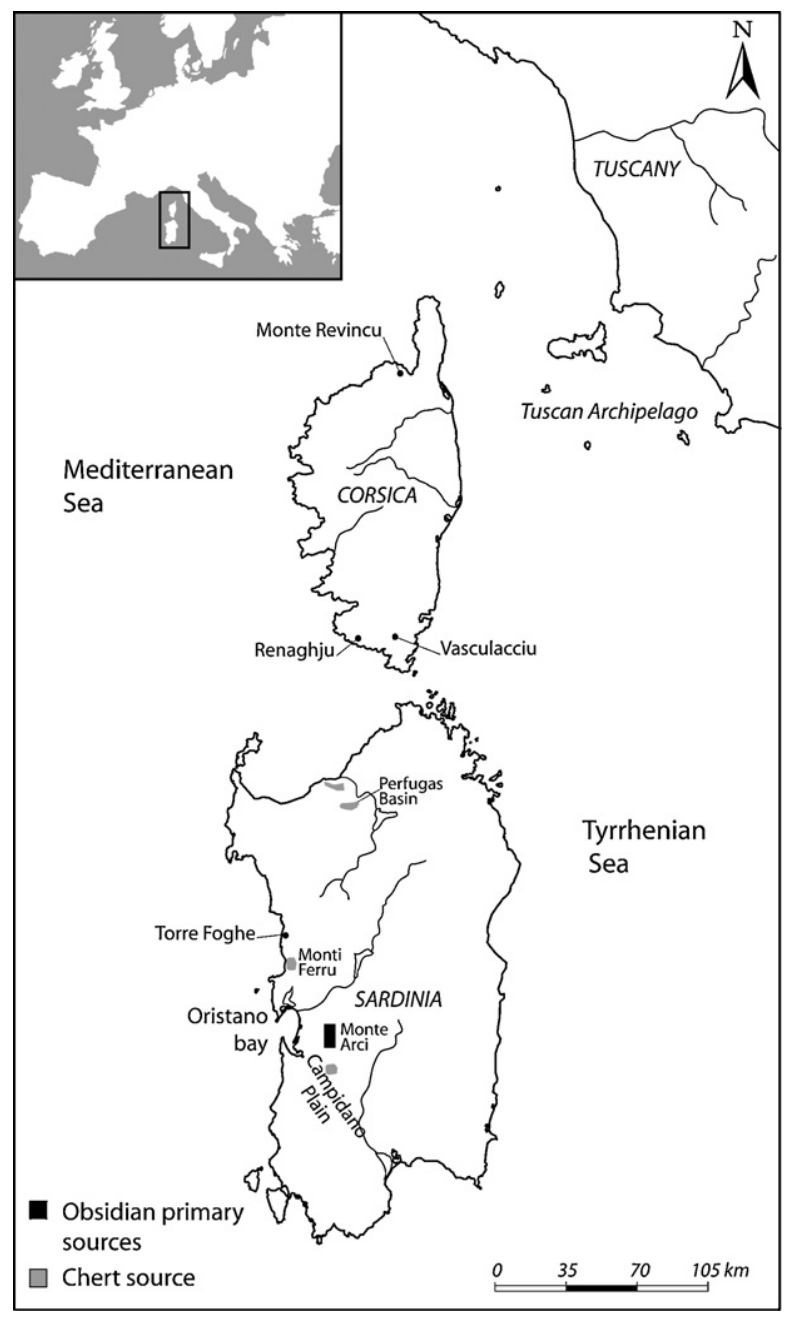

Fig. 1. Location of the Corsican sites studied, Sardinian obsidian sources and chert sources surveyed.

Fig. 1. Localisation des sites corses étudiés, des sources sardes d'obsidienne et de silex prospectées. 
Provenance studies of Neolithic raw materials are still scarce in Corsica. This can in part be related to the difficult characterization of materials as quartz, rhyolites and cherts, and to the lack of reference source samples. In the case of obsidians, the works were often only carried out on a small number of samples from poorly dated sites. Integrated studies of raw materials origin are of importance to understand the relationship between cultural evolution of Corsica and regional interactions. We present here the results of a chert and obsidian provenance study for the 6th millennium site of Renaghju and the 5th millennium sites of Monte Revincu and Vasculacciu, currently excavated or studied.

\section{The sites and their lithic industry}

\subsection{Renaghju}

The site of Renaghju is located on the Cauria plateau, in the Southwest of Corsica, close to Sartène. At an altitude of about $110 \mathrm{~m}$, it is separated from the sea shore, $2.5 \mathrm{~km}$ away, by a granitic massif culminating at $267 \mathrm{~m}$. This part of 'Hercynian' Corsica displays calcoalkaline granitoids cut by quartz, dolerite, and rhyolite veins [41,42].

During the excavation of the megalithic site [21,22], the remains of a Cardial Early Neolithic settlement (Renaghju phase 1) have been discovered at the base of the stratigraphy (phase 1). The settlement showed preserved dwelling structures associated with ceramics of the Filiestru-Basi-Pienza style and a rich lithic industry [20].

Four ${ }^{14} \mathrm{C}$ ages obtained from charcoal associated with four heated stones structures show that the site was occupied during the 6th millennium BC (Table 1).
The lithic assemblage of Renaghju phase 1 is composed of 30\% quartz (milky and less frequently hyaline), $9 \%$ rhyolite, $46 \%$ chert and $15 \%$ obsidian (Table 2 ).

The debitage of quartz aimed at the production of flakes and, occasionally, on hyaline quartz, of bladelets. Rhyolite industry is mostly composed of flakes with the scarce occurrence of laminar products and rare geometric armatures. Chert and obsidian are dedicated to the production of blades and bladelets and are frequently transformed into geometric armatures and truncations. The first stages of the chaîne opératoire are represented among the industry, but we observed a deficit in nucleus.

The provenance study was conducted on the whole chert corpus and on 41 obsidians.

\subsection{Monte Revincu}

The site of Monte Revincu, excavated intermittently since 1995, is located in the area of the Agriate in the northern part of Corsica [33,34]. The prehistoric settlement extends over the foothills of the Monte Revincu (356 $\mathrm{m}$ high), which overhangs the plain of Casta to the south and the Saint-Florent gulf to the north. The Agriate belongs to the Tenda massif, situated between the Balagne granitoids to the west and the lustrous shales of Alpine Corsica to the east.

The site consists of more than 40 stone structures, among which have been identified three dolmens, at least four cists graves and 35 rectangular structures related to domestic activities.

The dating of six structures shows a simultaneous use of the dwelling site and of sepulchral monuments between 4300 and $4000 \mathrm{BC}$ (Table 1). Those dates are the earliest to document megalithic culture in Corsica. They support recent hypotheses about the emergence of insular

Table 1

Radiocarbon dating of Renaghju phase 1 and Monte Revincu. US: Stratigraphical Unit. Calibration data used: P.J. Reimer et al. [46]

Tableau 1

Datations radiocarbone de la phase 1 de Renaghju et du Monte Revincu. US : unité stratigraphique. Données de calibration utilisées : P.J. Reimer et al. [46]

\begin{tabular}{|c|c|c|c|c|c|c|c|}
\hline Site & Phase/structure & US & Lab. reference & Sample & $\mathrm{BP}$ & \pm & $\mathrm{BC}$ \\
\hline Monte & Structure 6 & US 102 & Ly-8395 & Charcoal & 5355 & 55 & $4334-4042$ \\
\hline \multirow[t]{5}{*}{ Revincu } & Cist D & US 78 & Ly-8396 & Charcoal & 5405 & 55 & $4348-4056$ \\
\hline & Cist $\mathrm{C}$ & US 920 & Ly-9713 & Charcoal & 5405 & 70 & $4359-4046$ \\
\hline & Hearth near cist $\mathrm{D}$ & US 502 & Ly 9095 & Charcoal & 5175 & 45 & $4045-3848$ \\
\hline & Celluccia dolmen & US6 & Poz-13801 & Charcoal & 5410 & 40 & $4341-4174$ \\
\hline & Dolmen of Urcu & US 995 & Ly 13092 & Charcoal & 5355 & 50 & $4331-4044$ \\
\hline \multirow[t]{4}{*}{ Renaghju } & Phase 1 & US 61 & Ly-9519 & Charcoal & 6769 & 41 & $5726-5622$ \\
\hline & Phase 1 & US 104 & Ly-8327 & Charcoal & 6525 & 60 & $5611-5370$ \\
\hline & Phase 1 & US 66 & Ly-8328 & Charcoal & 6095 & 45 & $5206-4854$ \\
\hline & Phase 1 & US 75 & Ly-11262 & Charcoal & 6290 & 40 & $5324-5212$ \\
\hline
\end{tabular}


Table 2

Distribution and nature of lithic raw materials in the three studied sites. EN, Early Neolithic; MN, Middle Neolithic. $N($ tot $)$, total number of artefacts Tableau 2

Distribution et nature des matières premières lithiques dans les trois sites étudiés. EN, Néolithique ancien ; MN, Néolithique moyen. $N($ tot), nombre total d'artefacts

\begin{tabular}{|c|c|c|c|c|c|c|c|c|c|}
\hline \multirow[t]{2}{*}{ Site } & \multirow[t]{2}{*}{ Period } & \multirow[t]{2}{*}{$N($ tot $)$} & \multicolumn{4}{|c|}{ Autochtonous (Corsica) } & \multicolumn{3}{|c|}{ Allochthonous } \\
\hline & & & Quartz & Rhyolite & Other & $N($ tot $)$ & Obsidian & Chert & $N($ tot $)$ \\
\hline Vasculacciu* $^{*}$ & $\mathrm{MN}$ & 2860 & $\begin{array}{l}183 \\
6.4 \%\end{array}$ & $\begin{array}{l}89 \\
3.1 \%\end{array}$ & $\begin{array}{l}47 \\
1.6 \%\end{array}$ & $\begin{array}{l}319 \\
11.2 \%\end{array}$ & $\begin{array}{l}2303 \\
\quad 80.5 \%\end{array}$ & $\begin{array}{l}238 \\
\quad 8.3 \%\end{array}$ & $\begin{array}{l}2541 \\
\quad 88.8 \%\end{array}$ \\
\hline Monte Revincu** & MN & 7603 & $\begin{array}{l}7458 \\
98 \%\end{array}$ & $\begin{array}{l}32 \\
0.4 \%\end{array}$ & $\begin{array}{l}4 \\
0.05 \%\end{array}$ & $\begin{array}{l}7603 \\
\quad 98.6 \%\end{array}$ & $\begin{array}{l}77 \\
1 \%\end{array}$ & $\begin{array}{l}32 \\
0.4 \%\end{array}$ & $\begin{array}{l}109 \\
1.4 \%\end{array}$ \\
\hline Renaghju* & EN & 4303 & $\begin{array}{r}1276 \\
30 \%\end{array}$ & $\begin{array}{l}390 \\
9 \%\end{array}$ & 0 & $\begin{array}{l}1666 \\
38.7 \%\end{array}$ & $\begin{array}{l}653 \\
15 \%\end{array}$ & $\begin{array}{l}1984 \\
46 \%\end{array}$ & $\begin{array}{l}2637 \\
\quad 61.3 \%\end{array}$ \\
\hline
\end{tabular}

* 2003 inventory

** 1999 inventory

megalithic cultures within a Middle Neolithic context $[19,33]$.

The distribution of the lithic material varies only slightly between the structures. Quartz is always above $90 \%$ and on the average amounts to $98 \%$ (Table 2). Rhyolite, chert and obsidian are the other components. Among foreign materials, obsidian is the most abundant. Technological patterns of milky quartz are very similar to those of Renaghju. All stages of flake debitage were processed on site for this material. Hyaline quartz specimens are scarce, but testify to bladelet pressure debitage skills. The rhyolites, cherts and obsidians have not been knapped on the site, but introduced as end-products (armatures, pièces esquillées).

Twenty-six cherts were selected for a sourcing study. Most were associated with a stone structure situated at the foot of the Urcu dolmen (see ref. Ly-13092 in Table 1 for dating). Among the 19 obsidians sourced, 16 were collected in structure 8 (Cima di Suarello area), interpreted as a dwelling area.

\subsection{Vasculacciu}

Vasculacciu, located in southern Corsica, is an openair settlement that extends atop a monzogranite hill. It consists of a megalithic necropolis and a dwelling. The necropolis is composed of eight to ten megalithic burials, associated with several stone structures. Seven cists graves had been excavated in the 1960 s by Grosjean and Liégeois [25]. Since 1999, new investigations have been carried out [48]. No radiocarbon dating is available yet. However, a relative dating, based on ceramic chrono-typology, suggests the second half of the 5th millennium, i.e. an early phase of the Middle Neolithic [49].
Lithic assemblages come from burial and dwelling contexts inside an area of approximately $90,000 \mathrm{~m}^{2}$. Typotechnological studies showed a relative homogeneity of the industry. The lithic material is highly dominated by obsidian $(80.5 \%)$. Chert, quartz and rhyolite make almost all the complement, with $8.3 \%, 6.4 \%$ and $3.1 \%$, respectively (Table 2).

Obsidian blades were produced by direct percussion with a hard hammer for shaping stages and a soft hammer for advanced reduction phases. For this exotic material, all processing stages of the chaîne opératoire occurred in situ. Obsidian tools are dominated by pièces esquillées and, in lower proportions, by scrappers [49]. The debitage of other materials as chert, rhyolite and quartz is dedicated to flake production, seldom transformed in tools. The sourcing study was made on 231 cherts and 41 obsidians artefacts.

\section{Obsidian sourcing}

In the Western Mediterranean, archaeological obsidians can easily be sourced from their major elements contents $[24,53]$. We used this opportunity for the Vasculacciu obsidians. Millimetre-sized chips taken from the artefacts and 57 geological samples representative of the four Western Mediterranean types of obsidians were analyzed with an electron microprobe by wavelength dispersion spectrometry (EMP-WDS) at IFREMER (Brest), following the procedures described elsewhere [35]. The artefacts of Monte Revincu and of Renaghju were treated non-destructively by particleinduced X-ray emission (PIXE), which gives access to the content of 15 major to trace elements. The analyses were performed either with the external beam of the AGLAE facility of the 'Centre de recherche et de restau- 


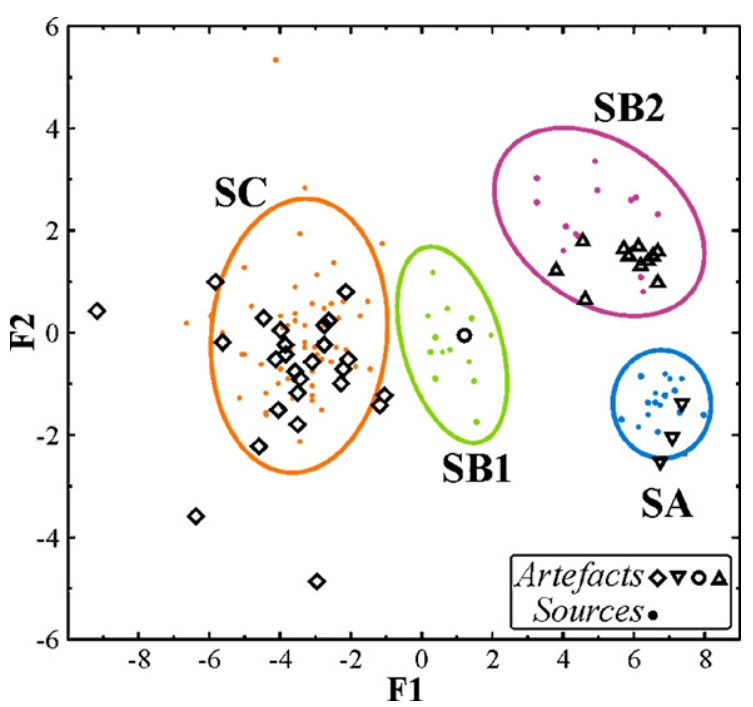

Fig. 2. Representation of EMP-WDS analyses of Vasculacciu artefacts plotted using discriminant functions (see text). The ellipses defining the Sardinian types of obsidians are calculated at a $90 \%$ confidence level from the contents of $\mathrm{Na}, \mathrm{Al}, \mathrm{Mg}, \mathrm{Si}, \mathrm{P}, \mathrm{K}, \mathrm{Ca}, \mathrm{Ti}$ and $\mathrm{Fe}$ determined for 101 geological samples [35, this work].

Fig. 2. Représentation des analyses EMP-WDS des artefacts de Vasculacciu au moyen des fonctions discriminantes (cf. texte). Les ellipses définissant les types sardes d'obsidiennes sont calculées à $90 \%$ de confiance pour les teneurs en $\mathrm{Na}, \mathrm{Al}, \mathrm{Mg}, \mathrm{Si}, \mathrm{P}, \mathrm{K}, \mathrm{Ca}$, Ti et Fe déterminées pour 101 échantillons géologiques [35, ce travail].

ration des musées de France' (Paris) for the Renaghju artefacts and for 11 Monte Revincu ones, or with the nuclear microprobe of the 'Centre d'études nucléaires de Bordeaux-Gradignan' (CENBG) for eight Monte Revincu artefacts. Sample preparation and data treatments are detailed elsewhere [4,36-38].

Both major and trace elements data indicate that all the archaeological obsidians analyzed come from Sardinia. A discriminant analysis of the EMP-WDS data performed with the XLSTAT software [1] shows that among the Vasculacciu artefacts, obsidians of all the Sardinian types are represented, although with a large predominance of the SB2 and SC types (Fig. 2, Table 3). The PIXE data for the Monte Revincu and Renaghju artefacts, notably their contents in $\mathrm{Al}, \mathrm{Ti}, \mathrm{Mn}, \mathrm{Zn}, \mathrm{Rb}$, $\mathrm{Sr}$ and $\mathrm{Zr}$, indicate that they were made only from SA, SB2 and SC obsidians (Table 3). This can be illustrated by bivariate diagrams, as those proposed in Fig. 3 .

\section{Chert sourcing}

Chert sourcing was realized based on their sedimentary microfacies, as defined from optical observations with a stereomicroscope at magnifications between $10 \times$ and $60 \times[2,7]$. Source assignments are proposed from
Table 3

Provenance of raw materials of the lithic industry

Tableau 3

Provenance des matières premières de l'industrie lithique

\begin{tabular}{lrcc}
\hline Provenance & Renaghju & Monte Revincu & Vasculacciu \\
\hline Sardinia & & & \\
Obsidian & 12 & 5 & 3 \\
SA & 0 & 0 & 1 \\
SB1 & 17 & 4 & 11 \\
SB2 & 11 & 10 & 26 \\
SC & 40 & 19 & 41 \\
Total & & & \\
Chert & 1331 & 0 & 7 \\
Perfugas & 0 & 0 & 11 \\
Montiferru & 217 & 17 & 190 \\
Unknown & 436 & 9 & 30 \\
Undeterminable & 1984 & 26 & 238 \\
Total & & & \\
\hline
\end{tabular}

comparisons with reference samples from northern Corsica pebbles, Sardinian chert source areas of Perfugas basin, Montiferru massif and Campidano plain, respectively (Fig. 1). The cherts in anyone of these three areas may present a variety of microfacies, for instance no less than 24 in the Perfugas basin, which are specific of

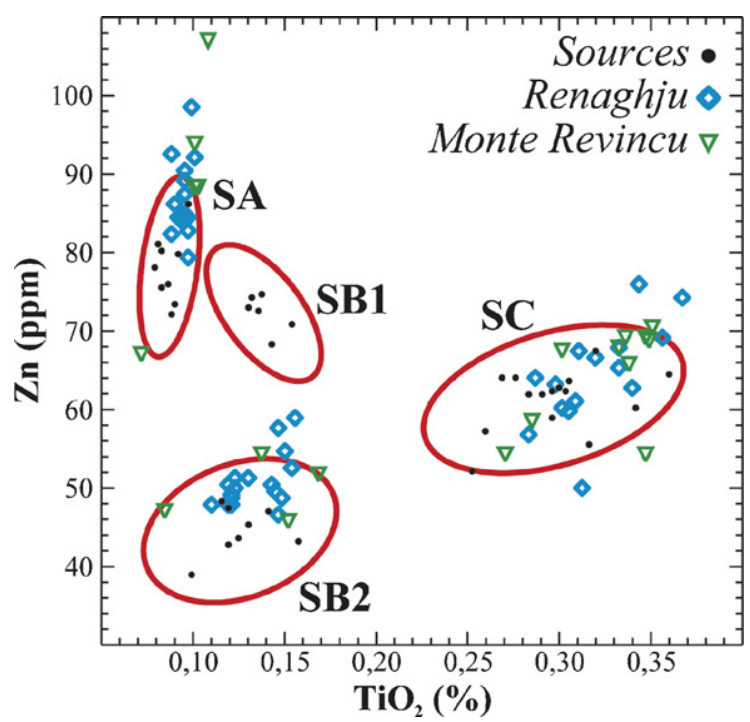

Fig. 3. Bivariate diagram of $\mathrm{Zn}$ and Ti contents as determined by PIXE in Monte Revincu and Renaghju obsidian artefacts and in Sardinian geological obsidians. Ellipses calculated from geological samples (data from $[37,38,45])$ for a $90 \%$ confidence level.

Fig. 3. Diagramme binaire des teneurs en Zn et Ti déterminées par PIXE dans les artefacts en obsidienne du Monte Revincu et de Renaghju et dans les obsidiennes géologiques sardes. Les ellipses sont calculées à partir des échantillons géologiques (données de [37,38,45]) avec un intervalle de confiance de $90 \%$. 
each one of these three source areas. Some limitations, however, may come from white patina or/and thermal alteration that affect(s) a variable fraction of cherts in a given assemblage. In such cases, depending on the importance of these effects, some cherts could only be classified as 'undeterminable'.

At Renaghju, we distinguished 24 types. Among the 1548 determinable cherts, $86 \%$ have a Sardinian origin from the Oligo-Miocene Basin of Perfugas [9] (Table 3). The facies variability observed among the archaeological assemblage partly reflects that of cherts from the Perfugas outcropping area, which extends over $15 \mathrm{~km}^{2}$. The facies of the remaining artefacts do not match any of our geological reference samples.

Monte Revincu cherts are characterized by six different facies. Among those, a recurrent one was found both in the Urcu area (five specimens) and in structure 8 (one specimen) of the archaeological site. Macroscopically, it is a grey translucent chert with white speckles. Under the stereomicroscope, microfossil remains (algal fragments, sponge spicules, radiolars) are indicative of a formation in a marine environment. This facies has also been observed in two other sites of the Nebbiu-Agriate massif and in Costa di U Monte, on the eastern coast of Corsica [40]. Another facies is represented by seven pieces that might come from the same artefact, fragmented by thermal alteration. None of the chert facies of Monte Revincu corresponds to those of the cherts from the Corsican or Sardinian source areas sampled until now, so that no provenance is proposed for this collection yet (Table 3).

At Vasculacciu, 11 chert facies were identified. Among them, one is similar to that of geological cherts from the Montiferru massif (Fig. 1, Table 3). Two other facies resemble that of the archaeological cherts from the Middle Neolithic site of Torre Foghe (Tres Nuraghes) [23] in the Centre-West coast of Sardinia (Fig. 1). However, the geological counterpart of the latter remains unknown.

\section{Discussion}

The lithic industries of Renaghju, Vasculacciu and Monte Revincu differ in many aspects and, in the first place, by their various fractions of artefacts, from $11 \%$ to 99\%, made from 'autochthonous' (Corsican) raw materials. Among these materials, quartz is always dominating ( $57 \%$ to $98 \%$ ), followed by rhyolites $(<1 \%$ to $24 \%$ ) and other kinds of rocks. Large variations are also found among allochtonous lithologies where obsidian and chert may vary inversely from $24 \%$ to $91 \%$. Such wide variations between Corsican Neolithic sites of the 6th and 5th millenniums were, however, not to be unexpected, as they were previously pointed out [15]. However, the number of well-dated sites of these periods for which detailed excavations were realized, quantitative data about the numbers of autochthonous/allochtonous raw materials available and, among the latter, the relative proportions of obsidians and cherts are quite small. Whereas about 25 and 18 sites may be attributed to the 6th and 5th millennia, respectively, from revised chronology [50], such information is only available for 19 out of them, as given in Table 4. In all cases, allochtonous raw materials are present, although in extremely variable relative abundances, from a few percent to $98 \%$. However, when the data are considered in the diachrony and the sites' localisations are taken into account, some striking behavioural differences appear between the sites of 'northern' Corsica, including the 'southernmost' Grotte Southwell, and of southern Corsica (Figs. 4 and 5).

In northern Corsica, the 'local' raw materials dominate largely the lithic implements, with always more than $70 \%$ of the artefacts. No notable differences appear between sites localized near to the coastlines or in coastal

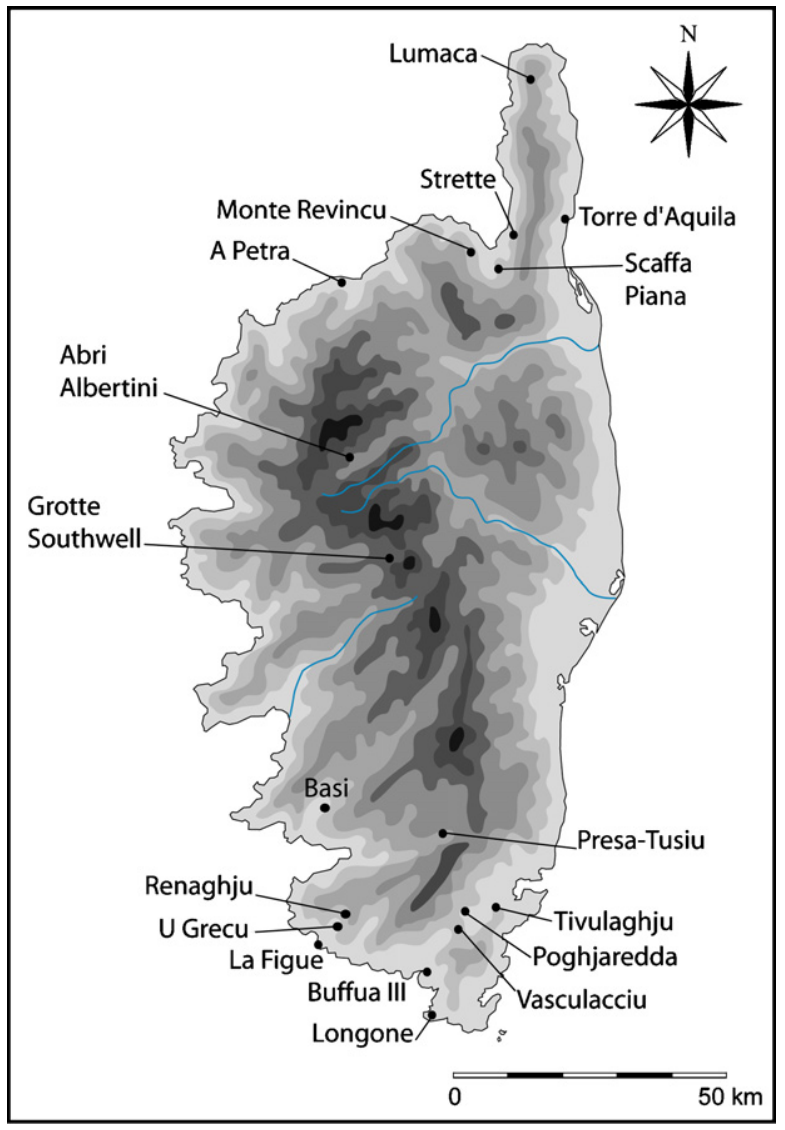

Fig. 4. Location of the Corsican Neolithic sites displayed in Table 4. Fig. 4. Localisation des sites néolithiques corses mentionnés dans le Tableau 4. 
Table 4

Synthesis of published data on raw material nature of Early and Middle Neolithic Corsican sites. NA: not available

Tableau 4

Synthèse des données publiées sur la nature des matières premières des sites corses du Néolithique ancien et moyen

\begin{tabular}{|c|c|c|c|c|c|c|c|}
\hline \multirow[t]{2}{*}{ Site } & \multirow[t]{2}{*}{ Layer } & \multirow[t]{2}{*}{ Dating } & \multirow[t]{2}{*}{$N($ tot $)$} & \multirow[t]{2}{*}{ Autochtonous (\%) } & \multicolumn{2}{|c|}{ Allochtonous (\%) } & \multirow[t]{2}{*}{ Reference } \\
\hline & & & & & Obsidian (\%) & Chert $(\%)$ & \\
\hline \multicolumn{8}{|c|}{ Middle Neolithic -5 th mil. BC } \\
\hline \multicolumn{8}{|c|}{ Northern Corsica } \\
\hline Scaffa Piana & XXI-XXII & ${ }^{14} \mathrm{C}$ & 846 & 91.1 & 8.5 & 0.4 & {$[15]$} \\
\hline Strette & XIV & Typology & 603 & 89.6 & 9.3 & 1.2 & [15] \\
\hline Torre d'Acquila & 5 & ${ }^{14} \mathrm{C}$ & NA & 89.0 & 11.0 & 0.0 & [39] \\
\hline Monte Revincu & & ${ }^{14} \mathrm{C}$ & 7603 & 98.0 & 1.0 & 0.4 & This study \\
\hline \multicolumn{8}{|l|}{ Southern Corsica } \\
\hline La Figue & & ${ }^{14} \mathrm{C}$ & 707 & 87.7 & 11.2 & 1.1 & {$[15]$} \\
\hline Tivulaghju & & Typology & 2434 & 13.0 & 81.7 & 5.3 & {$[50]$} \\
\hline Presa-Tusiu & 3 & ${ }^{14} \mathrm{C}$ & 1402 & 96.3 & 1.6 & 2.1 & {$[31]$} \\
\hline Renaghju & 3 & ${ }^{14} \mathrm{C}$ & 674 & 65.8 & 21.0 & 12.6 & D'Anna, unpublished data \\
\hline Poghjaredda & & Typology & 992 & 4.3 & 91.5 & 4.0 & {$[32]$} \\
\hline Vasculacciu & & Typology & 2860 & 11.2 & 80.5 & 8.3 & This study \\
\hline \multicolumn{8}{|c|}{ Cardial Early Neolithic -6 th mil. BC } \\
\hline \multicolumn{8}{|c|}{ Northern Corsica } \\
\hline A Petra & & ${ }^{14} \mathrm{C}$ & 140 & 97.9 & 1.4 & 0.7 & {$[15]$} \\
\hline Strette & $\mathrm{XXb}$ & ${ }^{14} \mathrm{C}$ & 1036 & 83.9 & 11.3 & 4.8 & [17] \\
\hline Abri Albertini & & Typology & 917 & 77.3 & 1.2 & 21.5 & [15] \\
\hline Grotte Southwell & & Typology & 116 & 76.7 & 10.3 & 12.9 & {$[15]$} \\
\hline \multicolumn{8}{|l|}{ Southern Corsica } \\
\hline Longone & & ${ }^{14} \mathrm{C}$ & 40 & 15.0 & 20.0 & 65.0 & [15] \\
\hline Bufua III & & Typology & 159 & 27.7 & 50.9 & 21.4 & [15] \\
\hline Basi & 6 & ${ }^{14} \mathrm{C}$ & 615 & 23.4 & 4.2 & 72.4 & [16] \\
\hline Renaghju & 1 & ${ }^{14} \mathrm{C}$ & 4303 & 38.7 & 15.0 & 46.0 & This study \\
\hline U Grecu & & Typology & 320 & 76.3 & 5.3 & 15.3 & {$[15]$} \\
\hline
\end{tabular}

plains and inland sites, as Abri Albertini and Grotte Southwell. The slight apparent increase in the abundance of local material in sites attributed to the 5th millennium might result from a statistical effect (small number of sites documented).

The eleven sites of the southern end of Corsica display a more diversified pattern. The autochthonous materials represent always less than $40 \%$ of the lithic assemblages, but for three sites of the 5th millennium and one of the 6th millenium. One of those, Presia-Tusiu, localized upstream from a high valley is the farthest from the coastline. This situation and the nearby availability of quartz might account for more than $96 \%$ autochthonous material. However, no access problems might be invoked for the Renaghju site, where 'imported' obsidian and flints were more largely used during the preceding millennium. The third particular site is the coastal La Figue, characterized by an exploitation of littoral resources, into which apparently obsidian and especially cherts did not contribute much [44]. At last, further investigations will be required to explain the local procurement pattern of $U$ Grecu which status is not well-defined. Another striking difference between the 6th and the 5th millenniums is the change from a rather large use of flint to an impressive domination of obsidian among the allochtonous materials. This pattern had already been noticed on the basis of less quantitative data [12].

\subsection{Obsidian}

Among the 100 obsidian artefacts analyzed, only one was found to be of the SB1 Monte Arci type, at Vasculacciu. This is in agreement with earlier provenance studies that have shown that, among the four types of Monte Arci obsidians, only three, SA, SB2, and SC, were well represented in Neolithic assemblages, SB1 obsidians being only incidentally met. This was attributed to its lower knapping qualities rather than to raw material modules and frequency or source accessibility [37]. In Corsica, for the 6th and 5th millennia, the rare provenance studies realized until now bear often on less than 20 artefacts per site (Fig. 6). Even when several tens of artefacts were sourced, as for Basi, this still represents only a small fraction of the collected material (Table 4). Even taking into 

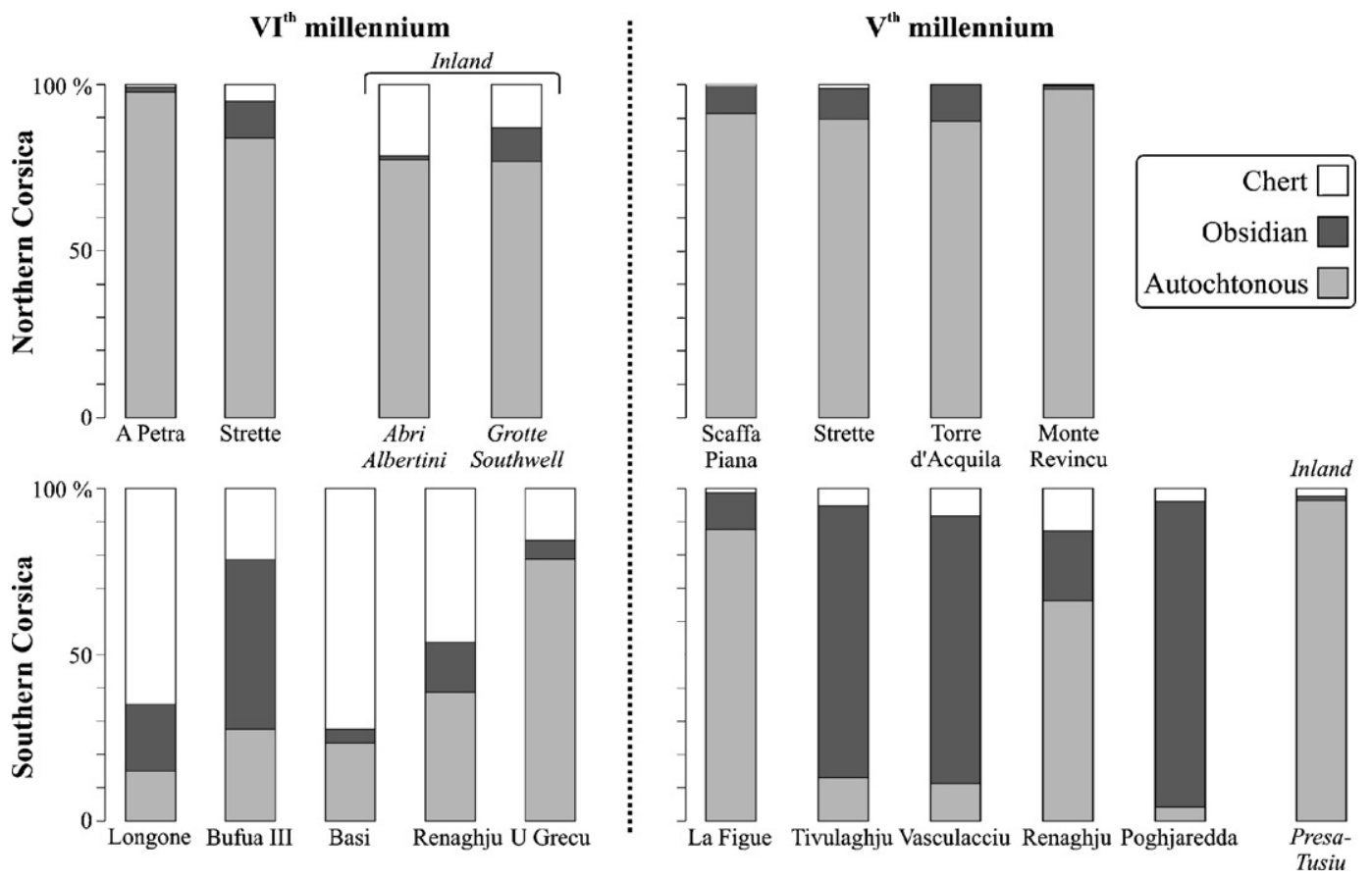

Fig. 5. Relative abundances of obsidian and chert as compared to autochthonous raw materials in Corsican sites of the 6th and 5th millenniums. Data from Table 4.

Fig. 5. Proportions relatives du silex et de l'obsidienne par comparaison avec les matières premières autochtones dans les sites corses des $\mathrm{VI}^{\mathrm{e}}$ et $\mathrm{V}^{\mathrm{e}}$ millénaires. Données du Tableau 4.

account these limitations, Fig. 6 might suggest a trend toward an increase with time of the use of SC obsidians relatively to SA and SB2 ones. A similar behaviour was observed by Tykot $[51,52,55]$ in Sardinia for the same periods. However, these proposals rely yet on too small numbers of sites and of analyses to be taken at face.

In other terms, although the constant presence of obsidians in Early and Middle Neolithic sites of Corsica and their sourcing to Sardinia show the continuity

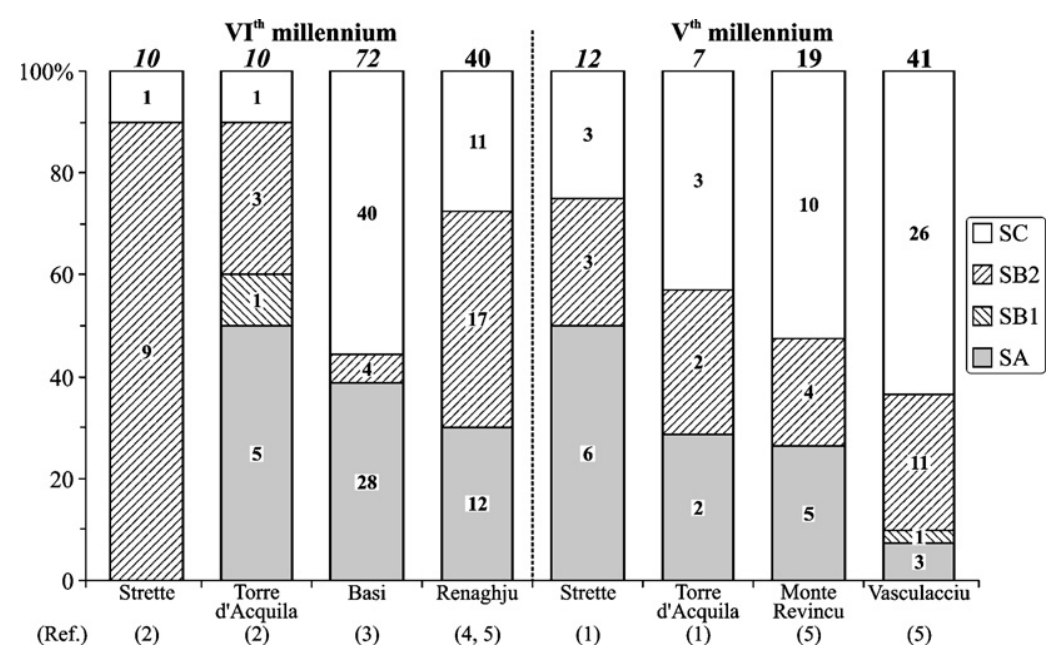

Fig. 6. Relative abundances of Monte Arci obsidians in Corsican sites of the 6th and 5th millenniums. Data from: (1) [56], (2) [55], (3) [54], (4) [9] and (5) this study. Note that the same Tykot data as reported by Costa (2006, Table 6) are often erroneous.

Fig. 6. Abondances relatives des obsidiennes du Monte Arci dans les sites corses des $\mathrm{VI}^{\mathrm{e}}$ et $\mathrm{V}^{\mathrm{e}}$ millénaires. Données d'après : (1) [56], (2) [55], (3) [54], (4) [9] et (5) ce travail. NB : les mêmes données de Tykot telles que rapportées par Costa (2006, Tableau 6) sont fréquemment erronées. 
of the relationship between the two islands, the present status of obsidian sourcing prevents any detailed discussion about the meaning of their relative abundances in any given site.

Stages of introduction and on-site consumption of obsidian vary from one site analysed to another. Indeed, although studies are still in progress, in particular for Renaghju and Vasculacciu, preliminary data show a shift from blade to bladelet debitage between the Early Neolithic site of Renaghju and the Middle Neolithic sites of Vasculacciu and Monte Revincu.

Whereas the different stages of the chaîne opératoire seem to be represented in both southern sites, Renaghju and Vasculacciu, obsidian is on the opposite introduced as end-products (mostly bladelets) in the northern Corsican site of Monte Revincu. It is worth to mention at this point that raw block imports have been recently evidenced at several Middle Neolithic sites of southern Corsica [50].

Technological constraints may have played a major part in the choice of raw material from Monte Arci, as pointed out by Lugliè for a Sardinian lithic study [37].

\subsection{Chert}

As for obsidian, identified provenances of chert of the three sites point to Sardinia. Whereas obsidian displays a single provenance region, the Monte Arci chert comes from several outcropping areas. However, a significant proportion of chert types, about $20 \%$ of the whole corpus, could not be related to any source. This suggests either a lack of reference source samples for Sardinia or that unassigned cherts might have come from a continental (Peninsular Italy?) area. This latter lead will soon be explored.

In the Corsican context, chert provenance studies is a rather pristine field of research. Other data on chert origins are not available yet, preventing us from considering our current results in a comparative perspective.

In Renaghju, evidences of introduction of raw blocks of chert or prepared nucleus for blade production are obvious. In both Middle Neolithic sites of Vasculacciu and Monte Revincu, cherts reach the site as flakes or end-products. Thus, from the 5th millennium onward, chert imports appear largely subordinated to the main diffusion lithic network involving obsidian.

The integrated study of obsidian and chert provenances and use raise a number of questions, among which the circulation modalities. Provisioning of Corsica with obsidian and chert does not match specialized networks patterns, as raw blocks and prepared nucleus are involved in circulations. It does not correspond to what would be expected from trade system. The actual provisioning behaviour, apprehended from Renaghju and Vasculacciu, rather recalls an acquisition within a single cultural entity. But differences may occur in raw material consumption as one gets farther from the sources.

\section{Conclusion}

Chert and obsidian provenances of the three study sites converge toward Sardinia. While obsidian geochemical analyses conclude systematically to a Monte Arci origin, chert assignments to Perfugas Basin or Oristano region introduce diversity and consequently complexity in circulation patterns between Sardinia and Corsica. However, some chert origins still remain unknown, which calls for more field surveys in Sardinia and more generally in the Tyrrhenian area.

Beside provenances, the three sites display specific procurement patterns in term of raw material distribution, pattern of transport and raw material consumption. Multiple factors may explain the variability of procurement patterns, among which site status seems to play a significant part. The shifts in raw material economy along the Neolithic ascertained from the three studied sites are reinforced when considering raw material spectra of contemporaneous Corsican sites. Further detailed study of Corsican sites raw material procurement may provide cultural or economic explanation of those shifts.

However, to fully understand the social and cultural phenomenon underlying lithic procurement patterns and their changes, it is necessary to consider Corsica and Sardinia in the same perspective, as they show strong connections throughout the Neolithic. We thus need comparable data on lithics of both Tyrrhenian islands. At first glance, the state of the art shows that Sardinian lithic studies are at the same point of progress as in Corsica. Thus, a tight collaboration is foreseen to develop further systematic studies on raw material procurement in the Tyrrhenian area.

\section{Acknowledgements}

The authors thank, for access to and assistance with PIXE analyses, J.-C. Dran, B. Moignard, L. Pichon, J. Salomon at the 'Centre de recherche et de restauration des musées de France' (Paris) and P. Moretto at the 'Centre d'études nucléaires de Bordeaux-Gradignan'. Thanks to M. Bohn (IFREMER, UMR 6538, Brest) for the microprobe analyses, C. Lugliè (University of Cagliari, Sardinia) for fruitful discussions and his field expertise on Sardinian raw material sources. The authors 
are grateful to C. Tozzi and M. Dini for the examination of some archaeological raw materials, and to C. Oberlin, who provided a revised calibration of the dating of the Corsican sites studied. We also thank Jean Guilaine and one anonymous reviewer for their comments and suggestions.

The obsidian samples of Vasculacciu were provided by Laurent J. Costa in the frame of an ACR project on Corsica. The analyses were partly funded by the French 'Ministère de la Culture', the GDR 2114 of CNRS 'Physico-chimie des matériaux du patrimoine culturel' (ChimArt2) and Eu-Artech.

\section{References}

[1] Addinsoft, XLSTAT 2007, Data Analysis and Statistics Software for Microsoft Excel, 2007, Paris, France.

[2] J. Affolter, Provenance des silex préhistoriques du Jura et des régions limitrophes, in: Archéologie neuchâteloise 28, 2 tomes, Service et musée cantonal d'Archéologie, Neuchâtel, Switzerland, 2002.

[3] G. Bailloud, Fouilles d'un habitat néolithique et torréen à Basi (Serra-di-Ferro, Corse). Premiers résultats, Bull. Soc. prehist. Fr. 66 (1969) 367-384.

[4] L. Bellot-Gurlet, G. Poupeau, J. Salomon, Th. Calligaro, B. Moignard, J.-A. Barrat, L. Pichon, Obsidian provenance studies in archaeology: a comparison between PIXE and ICP, Nuclear Instruments and Methods in Physics Research B 240 (2005) 583-588.

[5] D. Binder, Éléments pour la chronologie du Néolithique ancien à céramique imprimée dans le Midi, in: J.-L. Voruz (Ed.), Chronologies néolithiques. De 6000 à 2000 avant notre ère dans le Bassin rhodanien, Actes du colloque d'Ambérieu-en-Bugey, France, septembre 1992, $\mathrm{XI}^{\mathrm{e}}$, document du département d'anthropologie et d'écologie de l'université de Genève 20, Société préhistorique rhodanienne, Ambérieu-en-Bugey, 1995, pp. 55-65.

[6] D. Binder, J. Guilaine, La Méditerranée centrale et occidentale. Rapport du groupe de travail sur la néolithisation, Actes du $3^{\mathrm{e}}$ congrès international ${ }^{14} \mathrm{C}$ et Archéologie», Mémoire de la Société préhistorique française XXVI et Revue d'Archéométrie (suppl.), Paris et Rennes, 1999, pp. 454-459.

[7] C. Bressy, Caractérisation et gestion du silex des sites mésolithiques et néolithiques du Nord-Ouest de l'arc Alpin. Une approche pétrographique et géochimique, BAR Int. Ser. 1114 (2003) 1-295.

[8] C. Bressy, L. Bellot-Gurlet, A. D'Anna, D. Pelletier, P. Tramoni, Provenance et gestion des matières premières lithiques du site néolithique ancien cardial de Renaghju (Sartène, Corse-du-Sud), in: Les matières premières lithiques en Préhistoire, Actes de la table ronde internationale, Aurillac, France, June 2002, Préhistoire du Sud-Ouest, 2003, pp. 71-79.

[9] C. Bressy, L. Bellot-Gurlet, F. Convertini, A. D'Anna, J.-L. Guendon, D. Pelletier, P. Tramoni, Matières premières et circulation des matériaux dans le Néolithique ancien de Renaghju (Sartène, Corse-du-Sud), in: A. D'Anna, J. Cesari, L. Ogel, J. Vaquer, Corse et Sardaigne préhistoriques, relations et échanges dans le contexte méditerranéen, Actes des congrès nationaux des sociétés historiques et scientifiques, $128^{\mathrm{e}}$, Bastia, Corsica, France, 2003, document préhistorique ${ }^{\circ} 22,2007$, pp. 87-98.
[10] G. Camps, Préhistoire d'une île, Coll. des Hespérides, Errance, Paris, 1988.

[11] G. Camps, Peuplement des îles et navigations préhistoriques, L'homme préhistorique et la mer, Actes du $120^{\mathrm{e}}$ congrès national des sociétés historiques et scientifiques, Aix-en-Provence, 1995, CTHS, Paris, 1998, pp. 129-132.

[12] J. Cesari, J. Magdeleine, Le Néolithique et le Chalcolithique de la Corse : acquis et problèmes, in: J. Vaquer (Ed.), XXIV ${ }^{\mathrm{e}}$ Congrès préhistorique de France, Carcassonne, septembre 1994, Le Néolithique du Nord-Ouest méditerranéen, 1999, pp. 111-118.

[13] J. Cherry, The First colonization of the Mediterranean islands: a review of recent research, J. Mediterr. Archaeol. 3/2 (1990) 145-221.

[14] L.J. Costa, Espaces et sépultures mégalithiques en Corse, in: Ateliers 20, Des comportements techniques dans la préhistoire, Table ronde du laboratoire de Préhistoire et Technologie, mars 1999, 2000, pp. 239-258.

[15] L.J. Costa, Espaces et productions lithiques taillées en Corse $\left(9^{\mathrm{e}}-2^{\mathrm{e}}\right.$ millénaire cal. BC), thèse, université Paris-10, 2001.

[16] L.J. Costa, Récents acquis sur la circulation préhistorique de l'obsidienne en Corse, Bull. Soc. prehist. Fr. 103/1 (2006) 71-86.

[17] L.J. Costa, H. Paolini-Saez, M.-M. Ottaviani-Spella, J. Magdeleine, J.-C. Ottaviani, A. Berlinghi, Analyses de provenance des matériaux exploités à Strette (Barbaghju, HauteCorse): approche du fonctionnement du site au Néolithique ancien, Bull. Soc. prehist. Fr. 99/4 (2002) 785-791.

[18] G.M. Crisci, M. Ricq de Bouard, U. Lanzaframe, A.M. De Francesco, Nouvelle méthode d'analyse et provenance de l'ensemble des obsidiennes néolithiques du Midi de la France, Gallia Prehist. 36 (1994) 299-309.

[19] A. D'Anna, F. Leandri, Les alignements de menhirs du Sartenais. Table-ronde de Casta et Saint-Florent (Haute-Corse), in: A. D'Anna (Ed.), Table ronde 'Aspects du mégalithisme de la Corse, recherches en cours et perspectives', septembre 1999, Casta et Saint-Florent, Prehist. Anthropol. Mediterr. 9 (2000) 123-131.

[20] A. D’Anna, H. Marchesi, P. Tramoni, F. Demouche, C. Gilabert collab., Renaghju (Sartène, Corse-du-Sud), un habitat de plein air néolithique ancien en Corse, Bull. Soc. prehist. Fr. 98/3 (2001) 431-444.

[21] A. D'Anna, H. Marchesi, L. Pinet, P. Tramoni, J.-L. Guendon, Les alignements de menhirs de Renaghju dans leur contexte du plateau de Cauria (Sartène, Corse-du-Sud), in: Temps et espaces culturels du VI ${ }^{\mathrm{e}}$ au $\mathrm{II}^{\mathrm{e}}$ millénaire en France du Sud, Actes des IV ${ }^{\mathrm{es}}$ Rencontres méridionales de Préhistoire récente, Nîmes, France, October 2000, Mem. Archeol. Meridionale 15 (2003) 357-368.

[22] A. D'Anna, J.-L. Guendon, L. Pinet, P. Tramoni, Espaces, territoires et mégalithes : le plateau de Cauria (Sartène, Corse-du-Sud) au Néolithique et à l'âge du bronze, in: P. Duhamel (Ed.), Impacts interculturels au Néolithique moyen, Du terroir au territoire: sociétés et espaces, Actes du $25^{\mathrm{e}}$ colloque interrégional sur le Néolithique, octobre 2001, Rev. archeol. Est (25e suppl.) (2006) 191-214

[23] M. Dini, L'industria in ossidiana dei siti neolitici di Santa Caterina di Pittinuri e Torre Foghe sulla costa occidentale della Sardegna, in: C. Tozzi, M.C. Weiss, Préhistoire et protohistoire de l'aire tyrrhénienne, 2007, pp. 195-202.

[24] V. Francaviglia, Characterization of Mediterranean obsidian sources by classical petrochemical methods, Preist. Alp. 20 (1984) 311-332.

[25] R. Grosjean, J. Liégeois, Les coffres mégalithiques de la région de Porto Vecchio, L'Anthropologie 68 (5-6) (1964) 527-548. 
[26] J. Guilaine, De la vague à la tombe, in: La conquête néolithique de la Méditerranée, Le Seuil, Paris, 2003.

[27] B.R. Hallam, S.E. Warren, C. Renfrew, Obsidian in the western Mediterranean: characterization by neutron activation analysis and optical emission spectroscopy, Proc. Prehist. Soc. 42 (1976) $85-110$.

[28] F. de Lanfranchi, L'obsidienne préhistorique corso-sarde: les échanges et les axes de circulation, Bull. Soc. prehist. Fr. 77 (4) (1980) 115-122.

[29] F. de Lanfranchi, Le Néolithique de Curacchiaghiu. Position chronologique et culture matérielle. Son importance dans l'ensemble corso-sarde, in: J. Guilaine et al. (Eds.), Premières communautés paysannes en Méditerranée occidentale, Actes du colloque international du CNRS, Montpellier, 1983, Ed. du CNRS, Paris, 1987, pp. 433-442.

[30] F. de Lanfranchi, Prénéolithique ou Mésolithique insulaire ? Bull. Soc. prehist. Fr. 95 (4) (1998) 537-545.

[31] F. de Lanfranchi, Le village néolithique de Presa, Ed. Alain Piazzola, Ajaccio, 2003.

[32] F. de Lanfranchi, L.J. Costa, Nouvelles données et hypothèses relatives à la connaissance du Mégalithisme de Corse (l'exemple de Poghjaredda), L'Anthropologie 104 (2000) 549-567.

[33] F. Leandri, F. Demouche, L.-J. Costa, C. Gilabert, L. Pinet, Note sur la fouille du Monte Revincu et les prospections dans le Nebbio et les Agriates, in: A. D'Anna (Ed.), Table ronde 'Aspects du mégalithisme de la Corse, recherches en cours et perspectives', September 1999, Casta et Saint-Florent, Prehist. Anthropol. Mediterr. 9 (2000) 113-121.

[34] F. Leandri, F. Demouche, L.-J. Costa, P. Tramoni, C. Gilabert, A. Béraud, C. Jorda, Le site du Monte-Revincu (Santo-Pietrodi-Tenda, Haute-Corse): Contribution à la connaissance du Néolithique moyen de la Corse, in: A. D'Anna, J. Cesari, L. Ogel, J. Vaquer, Corse et Sardaigne préhistoriques, relations et échanges dans le contexte méditerranéen, Actes des congrès nationaux des sociétés historiques et scientifiques, $128^{\mathrm{e}}$, Bastia, Corsica, France, avril 2003, document préhistorique 22, 2007, pp. 165-183.

[35] F.-X. Le Bourdonnec, C. Lugliè, S. Dubernet, M. Bohn, G. Poupeau, Monte Arci (Sardinia) obsidians: New geochemical data from electron microprobe and ion beam analysis, in: L'ossidiana del Monte Arci nel Mediterraneo, PTM Editrice, Mogoro, Italy, 2005, pp. 129-140.

[36] F.-X. Le Bourdonnec, S. Delerue, S. Dubernet, P. Moretto, T. Calligaro, J.-C. Dran, G. Poupeau, PIXE characterization of Western Mediterranean and Anatolian obsidians and Neolithic provenance studies, Nucl. Instrum. Methods Phys. Res. B 240 (2005) 595-599.

[37] C. Lugliè, F.-X. Le Bourdonnec, G. Poupeau, E. Atzeni, S. Dubernet, P. Moretto, L. Serani, Early Neolithic obsidians in Sardinia (Western Mediterranean): the Su Carroppu case, J. Archaeol. Sci. 34 (3) (2007) 428-439.

[38] C. Lugliè, F.-X. Le Bourdonnec, G. Poupeau, C. Congia1, T. Calligaro, I. Sanna, S. Dubernet, Obsidian Economy in the Rio Saboccu Open-Air Early Neolithic Site (Sardinia, Italy), in: F. Sternke, L.J. Costa, L. Eigeland (Eds.), Non-flint Raw Material Use in Prehistory: Old Prejudices and New Directions, Proceedings of the 15th Congress of the International Union of the Prehistoric and Protohistoric Sciences, Archaeopress, Oxford, $\mathrm{UK}$, in press.

[39] J. Magdeleine, Préhistoire du cap Corse: Les abris de Torre d'Aquila, Pietracorbara (Haute-Corse), Bull. Soc. prehist. Fr. 92 (3) (1995) 363-377.
[40] N. Marini, Occupation and environmental context of a Prehistoric and Protohistoric settlement on the Corsican east coast, in: Cultural Heritage, The First International Symposium on Environment Identities and Mediterranean Area, July 2006, Corte-Ajaccio, Corsica, France, IEEE France section, 2006, pp. 461-466.

[41] J. Marre, O. Conchon, A. Gauthier, Carte géologique de France 1/50 000, feuille de Roccapina (1126), Ed. BRGM, Orléans, France, 1986.

[42] J. Marre, P. Rossi, O. Conchon, A. Gauthier, Notice explicative, Carte géologique de France 1/50 000, feuille Roccapina (1126), Ed. BRGM, Orléans, France, 1994.

[43] H. Paolini-Saez, F.-X. Le Bourdonnec, G. Poupeau, M.-M. Ottaviani-Spella, E. Pereira, P. Tramoni, A. Berlinghi, S. Lorenzo, I. Topi Pinnuti, M. Salotti, A Teppa di u Lupinu : Étude de provenance du mobilier des hommes établis à Santu-Petru-di-Tenda (Haute-Corse) au Néolithique moyen, Et. Corses, in press.

[44] A. Pasquet, P. Tramoni, L'occupation d'une zone littorale rocheuse au Néolithique moyen : l'exemple de l'abri de la Figue (Sartène, Corse-du-Sud), in : G. Camps (Ed.), L'Homme préhistorique et la Mer, Actes du $120^{\mathrm{e}}$ Congrès national des sociétés savantes, Aix-en-Provence, Paris, 1998, pp. 277-295.

[45] G. Poupeau, L. Bellot-Gurlet, V. Brisotto, O. Dorighel, Nouvelles données sur la provenance de l'obsidienne des sites néolithiques du Sud-Est de la France, C. R. Acad. Sci. Paris, Ser. IIa 330 (2000) 297-303.

[46] P.J. Reimer, M.G.L. Baillie, E. Bard, A. Bayliss, J.W. Beck, C. Bertrand, P.G. Blackwell, C.E. Buck, G. Burr, K.B. Cutler, P.E. Damon, R.L. Edwards, R.G. Fairbanks, M. Friedrich, T.P. Guilderson, K.A. Hughen, B. Kromer, F.G. McCormac, S. Manning, C. Bronk Ramsey, R.W. Reimer, S. Remmele, J.R. Southon, M. Stuiver, S. Talamo, F.W. Taylor, J. van der Plicht, C.E. Weyhenmeyer, Intcal04 terrestrial radiocarbon age calibration, 0-26 cal KYR BP, Radiocarbon 46 (3) (2004) 1029-1058.

[47] M. Salotti, L. Bellot-Gurlet, J.-Y. Courtois, J.-N. Dubois, A. Louchart, C. Mourer-Chauviré, C. Oberlin, E. Pereira, G. Poupeau, P. Tramoni, La fin du Pléistocène supérieur et le début de l'Holocène en Corse: apports paléontologique et archéologique du site de Castiglione (Oletta, Haute-Corse), Quaternaire 11 (3-4) (2000) 219-230.

[48] P. Tramoni, A. D’Anna, J.-L. Guendon, J.-B. Orsini, L. Pinet, Vasculacciu: une grande nécropole mégalithique du Sud de la Corse, Et. corses 56 (2003) 1-28.

[49] P. Tramoni, A. D’Anna, L. Pinet, J.-L. Guendon, J.-B. Orsini, La nécropole mégalithique de Vasculacciu (Figari, Corse-duSud), in: H. Dartevelle (Ed.), Auvergne et Midi - Actualité de la recherche: actes de la cinquième session des Rencontres méridionales de Préhistoire récente, Clermont-Ferrand (Puyde-Dôme), novembre 2002, Préhistoire du Sud-Ouest, 2004, pp. 523-536.

[50] P. Tramoni, A. D'Anna, A. Pasquet, J.-L. Milanini, R. Chessa, Le site de Tivulaghju (Porto-Vecchio, Corse-du-Sud) et les coffres mégalithiques du Sud de la Corse, nouvelles données, Bull. Soc. prehist. Fr. 104 (2) (2007) 245-274.

[51] R.H. Tykot, The sources and distribution of Sardinian obsidian, in: R.H. Tykot, T.K. Andrews (Eds.), Sardinia in the Mediterranean: a footprint in the sea. Studies in Sardinian Archaeology presented to Miriam S. Balmuth, Monograph in Mediterranean Archaeology, Sheffield Academic Press, Sheffield, UK, 1992, pp. 57-70.

[52] R.H. Tykot, Obsidian procurement and distribution in the Central and Western Mediterranean, J. Mediterr. Archaeol. 9 (1) (1996) 39-82. 
[53] R.H. Tykot, Characterization of the Monte-Arci (Sardinia) obsidian sources, J. Archaeol. Sci. 24 (1997) 467-479.

[54] R.H. Tykot, Mediterranean islands and multiple flows: the sources and exploitation of Sardinian obsidian, in: M.S. Shackley (Ed.), Archaeological Obsidian Studies, Plenum Press, New York, 1998, pp. 67-82.

[55] R.H. Tykot, Geochemical analysis of obsidian and the reconstruction of trade mechanisms in the Early Neolithic of the western Mediterranean, in: K. Jakes (Ed.), Archaeological Chemistry, Materials, Methods and Meaning, ACS Symp. Ser. 831, American Chemical Society, Washington, DC, 2002, pp. 169-184.

[56] R.H. Tykot, New approaches to the characterization and interpretation of obsidian from the Mediterranean island sources, Materials Issues in Art and Archaeology VI, in: P.B. Vandiver, M. Goodway, J.R. Druzik, J.L. Mass (Eds.), Materials Research Society Proceedings 712, Warrendale, PA, USA, 2002, pp. 143-157.
[57] S. Van Willigen, Le Cardial franco-ibérique et le début du Néolithique en Méditerranée occidentale, in: J. Guilaine, P.L. Van Berg, Actes du $14^{\mathrm{e}}$ congrès de l'Union internationale des sciences préhistoriques et protohistoriques, septembre 2001, Liège, Belgique, British Archaeological Reports, International series 1520, 2006, pp. 1-8.

[58] J.-D. Vigne, V. Bourdillat, J. André, J.-E. Brochier, Bui Thi Mai, J. Cuisin, H. David, N. Desse-Berset, C. Heinz, F. de Lanfranchi, M.-P. Ruas, S. Thiébault, C. Tozzi, Nouvelles données sur le Prénéolithique corse: premiers résultats de la fouille de l'abri du Monte Leone (Bonifacio, Corsedu-Sud, in: A. D'Anna, D. Binder (Eds.), Production et identité culturelle, actualités de la recherche, Rencontres méridionales de préhistoire récente, actes de la deuxième session, Arles, France, November 1996, APDCA, Antibes, France,1998, pp. 251-260. 